\title{
Seasonal Variability of I-129 \\ Concentrations in a Wetland \\ Receiving Contaminated Groundwater
}

\author{
R. L. NiChOLS ${ }^{1}$, D. I KAPLAN ${ }^{1}$, J. J. THIBAULT ${ }^{2}$, K. D. \\ BOERSTLER $^{2}$
}

${ }^{1}$ Savannah River National Laboratory, Aiken, SC 29808

USA (*correspondence: ralph.nichols@srnl.doe.gov)

${ }^{2}$ Savannah River Nuclear Solutions, Aiken, SC 29808 USA

Low-level acidic radioactive waste generated during operation of the F and H Areas at the Savannah River Site (SRS) from 1955 to 1988 was disposed in unlined earthen seepage basins. Liquid waste in the seepage basins infiltrated through the vadose zone, contaminating the underlying aquifer. Contaminated groundwater in the shallow aquifer subsequently migrated towards surface outcrops in the downgradient wetland. Dissolved concentrations of I-129 have been observed to exhibit seasonal variability in surface water samples collected from seeps in a wetland located on the SRS in the southeastern United States, Figure 1.

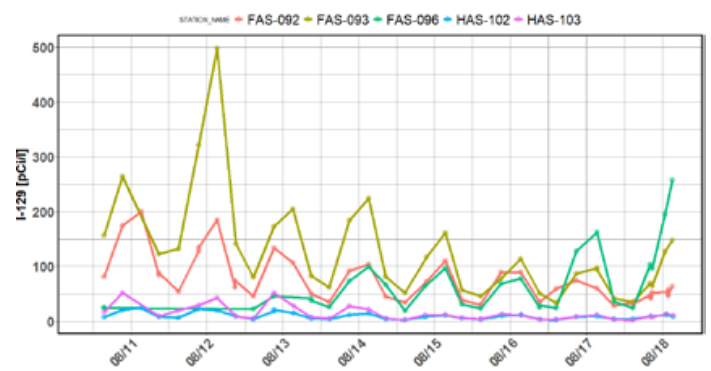

Figure 1 Seasonal variability of I-129 at 5 seepline locations.

The seasonal variability has a repeatable pattern where the highest concentrations are observed in the late spring and summer months and lowest concentrations are observed in late fall through winter resulting in changes in concentration as large as 300 percent over a one year period. This seasonal variability may be the result of dynamic hydrology in the wetlands or biogeochemical effects or both. A characterization program has been undertaken to elucidate further the causes of the variability to obtain knowledge that can be incorporated into ongoing remedial actions to accelerate restoring water quality and reduce the environmental footprint of the remedial actions. This paper presents the analysis of 7 years of monitoring data collecetd on the surface in the wetlands and discusses the conceptual model being investigated to improve our understanding of the transport and fate of I-129 in the contaminated aquifer. 